Animal Health Research Institute,

Damanhour Branch.

\title{
INCIDENCE OF HEAVY METALS RESIDUES IN SALTED AND SMOKED FISH PRODUCTS
}

(With 4 Tables)

By

\author{
I.A. EL-KEWAIEY; OMAIMA I. ALI* \\ and OMAIMA A. SALEH
}

* Animal Health Research Institute (Toxicology Unit), Dokki, Egypt.

(Received at 13/9/2011)

مدى تواجد بقايا المعادن الثقيلة فى منتجات الاسماك المملحة والمدخنة

$$
\text { ابر/هيم على القوييحى ، أمبيمة ابر/هيم على ، أمبية عبل الفتاح صالح }
$$

أجريت هذه الدراسة لاستبيان مدى تو اجد المعادن الثقيلة فى أسماك السردين المملحة وأسماك

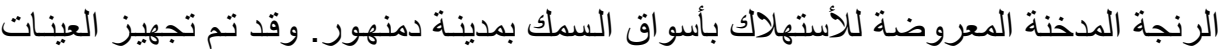

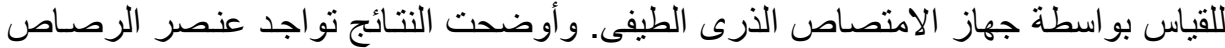

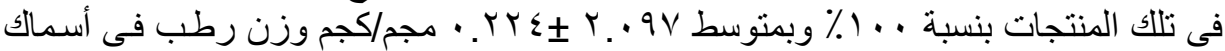

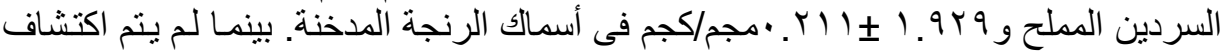

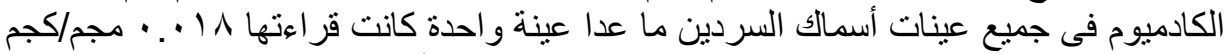

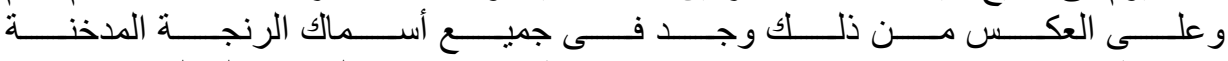

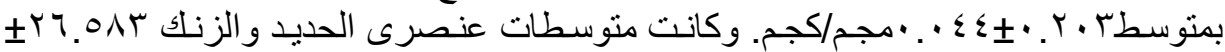
1 1

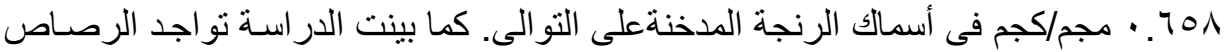

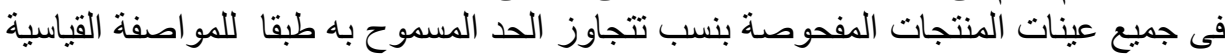

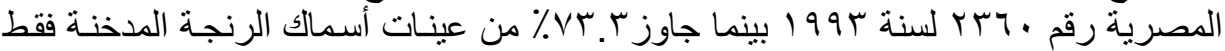

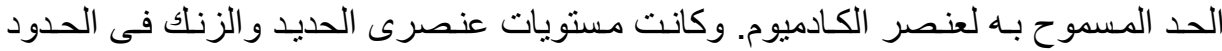

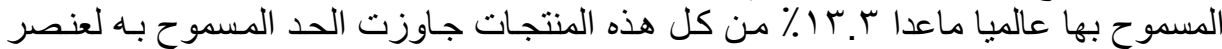

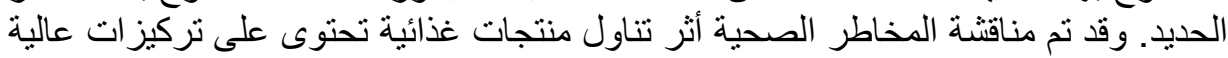

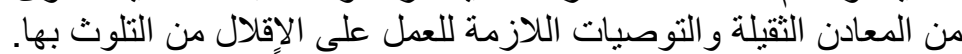

\section{SUMMARY}

A total of thirty samples of salted sardine and smoked herring fishes (15 of each) were randomely collected from fish markets in Damanhour city to estimate the concentrations of heavy metals using Flame Atomic Absorption Spectrophotometer. The obtained results showed that the 
mean values of lead in salted sardine and smoked herring were $2.097 \pm 0.224$ and $1.929 \pm 0.211 \mathrm{mg} / \mathrm{kg}$ wet weight, respectively, with an incidence of $100 \%$ of each. While cadmium residue was detected only in one sample of salted sardine, with a reading of 0.018 , but a mean value of $0.203 \pm 0.044 \mathrm{mg}$ cadmium $/ \mathrm{kg}$ was estimated in smoked herring with an incidence of $80 \%$. Meanwhile, the means of iron and zinc elements were $26.583 \pm 3.931$ and $15.996 \pm 1.432 \mathrm{mg} / \mathrm{kg}$ in salted sardine and were $27.81 \pm 3.686$ and $11.032 \pm 0.658 \mathrm{mg} / \mathrm{kg}$ in smoked herring. The lead levels in all the examined samples of both fish products were above the permissible limit of Egyptian Organization of Standardization and Quality Control "EOSQC" (1993). Cadmium residues levels exceeded the permissible limit in $73.3 \%$ of smoked herring fish. The levels of both iron and zinc were within the permissible $\mathrm{FAO} / \mathrm{WHO}$ guidelines except $13.3 \%$ of both fish products exceeded iron permissible limit. The health hazard of contaminated food products with heavy metals and the essential recommendations which should be taken were disccussed to safeguard the consumers.

Key words: Fish, salted fish, smoked fish, heavy metals, lead, iron, zinc, cadmium.

\section{INTRODUCTION}

Fish had long been regarded as a desirable and nutritional source of high quality protein and generous supply of minerals and vitamins. Smoked fish is widely consumed all over the world because of its high protein, low saturated fat, fat soluble vitamins, essential minerals and omega fatty acids known to support good health (Ikem and Egiebor, 2005) so, salted and smoked fishery products continues to occupy its important place as delicacy in the dishes of Egyptians.

Traditional fish products are usually produced by applying old preserving methods such as salting, fermenting, drying and smoking. These products are greatly varied amongst the countries as well as within the same country by using many different applications such as differences in additives, percentage of salt or vinger and maturing temperatures. Although such processing/preserving methods have been known as still old techniques for many decades, they still have wide acceptance around the world because of their specific taste and aroma.

Smoking process is considered as a sequal to curing, the result is a dry, golden brown surface which is imperative, besides, the wood 
smokes that are deposited on the fish products, inhibit the development of spoilage microorganisms and act as antioxidant (Fretheim et al., 1980). The polluted salted and smoked fish constitute a consumer's health risk in Egypt especially in certain national occasions as feasts and Sham El-Neseem because a lot of these products are prepared by old traditional methods and consumed as ready-to-eat food. Salted sardine is produced by salting sardine fishes for a relatively long period with unrefined table salt (estimated as sodium chloride, 15-22\%) fulfilled of impurities that included heavy metals to reduce the cost (Salah El-Dien et al., 2005). Smoke was carried some heavy metals which may adsorped on smoked fish. Moreover salted and smoked fishes may be exposed to heavy metals pollutions during their sea-life before catching and processing (Küçüksezgin et al., 2006). Heavy metals have been considered as dangerous substances causing a serious health hazard to human and animals, through progressive accumulation in their bodies as a result of a repeated consumption of small amount of these elements (Igado et al., 2008). Among possible humans target organs of heavy metals, soft tissues such as the kidneys, liver and central nervous system appear to be especially sensitive (Apostoli, 2002). Studies of heavy elements in sardines (or herring) have been limited chiefly to fresh specimens from the Mediterranean (Canli and Atli, 2003; Falco et al., 2006) and the northeast Atlantic (Food Standards Agency "FSA", 2005) and to canned products.

Therefore, it was important and necessary to conduct this study to determine the concentrations of some heavy metals in traditionally locally made salted sardine and smoked herring fishes and comparing the levels of pollution with the national and international permissible limits.

\section{MATERIALS and METHODS}

\section{A. Collection of samples:}

Thirty random fish products samples (15 each of salted sardine and smoked herring fishes) were collected at the consumer level from different fish markets of Damanhour city in El-Boheira governorate and each sample was wrapped in a light polyethylene bag and was placed in an ice box and was taken to the laboratory without delay.

\section{B. Preparation of collected samples:}


The collected fish products were washed with tape water several times and then with de-ionized water. The sample of each fish product was taken from the muscles below the dorsal fin and at the middle line, then was homogenized and was kept at fresh polyethylene bags at $-20^{\circ} \mathrm{C}$ until analysis. Each weighted sample was transferred into a clean and acid washed screw-capped glass digestion tubes. All digestion tubes were identified for chemical analysis.

\section{Digestion procedure:}

Each prepared sample of fish products was digested according to Al-Ghrais (1995) by addition of $10 \mathrm{mls}$ of nitric and perchloric acids mixture (4vol:1vol). Initial digestion was performed at room temperature for 4 hours followed by careful heating at $40-45^{\circ} \mathrm{C}$ for one hour in a water bath, then the temperature was raised to $75^{\circ} \mathrm{C}$ with gentle shaking untill digestion was completed within 2-3 hours. The digest was allowed to cool at room temperature then diluted up to $25 \mathrm{mls}$ with deionized water, then filtered through whatman's filter paper No.1. Blank solution was prepared to check the possible traces of heavy metals that may be present in the acids and deionized water which were used in the digestion and dilution of the samples. Lead, cadmium, iron and zinc levels were determined in all the examined samples by using Flame Atomic Absorpance Spectrophotometer (UNICAM 969 A.A. Spectrophotometer) in Toxicology Unit of the Animal Health Research Institute, Ministry of Agriculture, Dokki, Giza, Egypt.

Working condition for heavy metals analysis by atomic absorption spectrophotometer

\begin{tabular}{|c|c|c|c|c|c|c|}
\hline Metal & $\begin{array}{c}\text { Lamp wave } \\
\text { Length (nm) }\end{array}$ & $\begin{array}{c}\text { Slit width } \\
(\mathrm{nm})\end{array}$ & $\begin{array}{c}\text { Lamp } \\
\text { Current } \\
(\mathrm{mA})\end{array}$ & $\begin{array}{c}\text { Fuel flow } \\
\text { Rate } \\
(1 / \mathrm{min} .)\end{array}$ & $\begin{array}{c}\text { Burner } \\
\text { Height }(\mathrm{cm})\end{array}$ & $\begin{array}{c}\text { Detection } \\
\text { limit }\end{array}$ \\
\hline Lead $(\mathrm{Pb})$ & 217 & 0.7 & 12 & 30 & 8 & $0.02 \mathrm{ppm}$ \\
\hline $\begin{array}{c}\text { Cadmium } \\
(\mathrm{Cd})\end{array}$ & 228.8 & 0.7 & 5 & 30 & 8 & $0.0006 \mathrm{ppm}$ \\
\hline Iron (Fe) & 248.3 & 0.2 & 25 & 30 & 8 & $0.05 \mathrm{ppm}$ \\
\hline Zinc (Zn) & 213.9 & 0.7 & 10 & 30 & 8 & $0.002 \mathrm{ppm}$ \\
\hline
\end{tabular}

\section{Quantitive determination of heavy metals in the examined samples:}


The concentrations of lead $(\mathrm{Pb})$, cadmium $(\mathrm{Cd})$, iron $(\mathrm{Fe})$ and zinc $(\mathrm{Zn})$ in the examined samples were calculated according to the following equation: $\mathrm{C}=\mathrm{R} \times \mathrm{D} / \mathrm{W}$

Where: $\mathrm{C}=$ Concentration of heavy metals $(\mathrm{mg} / \mathrm{kg})$ wet weight.

$\mathrm{R}=$ Reading of element concentration on digital scale of AAS.

$\mathrm{D}=$ Final volume of prepared sample in mls.

$\mathrm{W}=$ Weight of the wet sample.

The reading of absorbance values of $\mathrm{Pb}, \mathrm{Cd}$, iron and zinc concentrations were recorded and the results of analysed samples were calculated.

The obtained data in this study were statistically analysed according to the method of Petric and Waston (2006).

\section{RESULTS}

Table 1: Level of heavy metal concentrations $(\mathrm{mg} / \mathrm{kg}$, wet weight) in the examined samples of salted sardine fishes $(n=15)$

\begin{tabular}{|c|c|c|c|c|}
\hline Element & Min. & Max. & Mean & S.E. \\
\hline Lead $(\mathrm{Pb})$ & 0.633 & 3.823 & 2.097 & 0.224 \\
\hline Cadmium (Cd) & ND & 0.018 & 0.001 & 0.001 \\
\hline $\operatorname{Iron}(\mathrm{Fe})$ & 12.973 & 68.78 & 26.583 & 3.931 \\
\hline Zinc $(\mathrm{Zn})$ & 8.713 & 25.063 & 15.996 & 1.432 \\
\hline $\begin{array}{l}\text { Min.:minmum } \\
\mathrm{mg} / \mathrm{kg}=\mu \mathrm{g} / \mathrm{g}=\mathrm{ppm}\end{array}$ & $\begin{array}{l}\text { Max.:max } \\
\text { ND : not }\end{array}$ & $d=14$ & $\begin{array}{l}\text { standard } \\
\text { s"93.3\%" }\end{array}$ & f mean \\
\hline
\end{tabular}

Table 2: Level of heavy metal concentrations ( $\mathrm{mg} / \mathrm{kg}$, wet weight) in the examined samples of smoked herring fishes $(n=15)$ 


\begin{tabular}{|c|c|c|c|c|}
\hline Element & Min & Max & Mean & S.E. \\
\hline Lead $(\mathrm{Pb})$ & 0.488 & 3.57 & 1.929 & 0.211 \\
\hline Cadmium $(\mathrm{Cd})$ & $\mathrm{ND}$ & 0.653 & 0.203 & 0.044 \\
\hline Iron (Fe) & 14.59 & 65.62 & 27.810 & 3.687 \\
\hline Zinc (Zn) & 6.858 & 16.45 & 11.032 & 0.658 \\
\hline
\end{tabular}

$\mathrm{ND}=3$ samples "20\%"

Table 3: Comparison of the estimated heavy metals residues in the examined fish products with the recommended national and international permissible limits $(\mathrm{n}=15)$.

\begin{tabular}{|c|c|c|c|c|c|c|c|c|c|}
\hline \multirow{3}{*}{ Element } & \multirow{3}{*}{$\begin{array}{c}\text { Permissible } \\
\text { Limit (PL) } \\
\mathrm{mg} / \mathrm{kg}\end{array}$} & \multicolumn{4}{|c|}{ Salted Sardine } & \multicolumn{4}{|c|}{ Smoked Herring } \\
\hline & & \multicolumn{2}{|c|}{$\begin{array}{l}\text { Within } \\
\text { PL }\end{array}$} & \multicolumn{2}{|c|}{ Over PL } & \multicolumn{2}{|c|}{ Within PL } & \multicolumn{2}{|c|}{ Over PL } \\
\hline & & No & $\%$ & No & $\%$ & No & $\%$ & No & $\%$ \\
\hline \multirow[t]{3}{*}{ Lead $(\mathrm{Pb})$} & $0.3^{\mathrm{a}}$ & 0 & 0 & 15 & 100 & 0 & 0 & 15 & 100 \\
\hline & $0.2^{\mathrm{b}}$ & 0 & 0 & 15 & 100 & 0 & 0 & 15 & 100 \\
\hline & $0.1^{\mathrm{c}}$ & 0 & 0 & 15 & 100 & 0 & 0 & 15 & 100 \\
\hline \multirow{2}{*}{$\begin{array}{l}\text { Cadmium } \\
\text { (Cd) }\end{array}$} & $0.1^{\mathrm{c}}$ & 15 & 100 & 0 & 0 & 4 & 26.7 & 11 & 73.3 \\
\hline & $0.05^{\mathrm{b}}$ & 15 & 100 & 0 & 0 & 3 & 20 & 12 & 80 \\
\hline $\operatorname{Iron}(\mathrm{Fe})$ & $40^{\mathrm{d}}$ & 13 & 86.7 & 2 & 13.3 & 13 & 86.7 & 2 & 13.3 \\
\hline $\operatorname{Zinc}(\mathrm{Zn})$ & $50^{\mathrm{e}}$ & 15 & 100 & 0 & 0 & 15 & 100 & 0 & 0 \\
\hline
\end{tabular}

${ }^{\mathrm{a}}$ Codex (2008).

${ }^{\mathrm{b}}$ Commission of the European Communities (2001).

${ }^{\mathrm{c}}$ Egyptian Organization for Standardization and Quality Control (E.O.S.Q.C.), Egyptian Specification Standard"E.S.S." No.2360 (1993).

${ }^{\mathrm{d}}$ Institute of Medicine (2003).

${ }^{\mathrm{e}} \mathrm{FAO}(1983)$ \& MAFF (1995).

Table 4: Estimated daily and weekly intakes by adults consuming fishery products 


\begin{tabular}{|c|c|c|c|c|c|c|}
\hline \multirow{2}{*}{ Element } & \multirow{2}{*}{$\begin{array}{c}\text { Provisional } \\
\text { Permissible } \\
\text { Tolerable } \\
\text { Weekly } \\
\text { Intakes (PTWI) } \\
\text { ( } \mu \mathrm{g} / \mathrm{kg} \text { body } \\
\text { weight) }\end{array}$} & \multirow{2}{*}{$\begin{array}{c}\text { Permissible } \\
\text { Tolerable } \\
\text { Intakes }(\mathrm{PTI}) / \mathrm{day} \\
\text { " } \mu \mathrm{g} / \mathrm{day} / 60 \mathrm{~kg} \\
\text { b.w."(PTDI, } \mu \mathrm{g} / \mathrm{kg} \\
\text { b.w.) }\end{array}$} & \multicolumn{2}{|c|}{ Salted Sardine } & \multicolumn{2}{|c|}{ Smoked Herring } \\
\hline & & & $\begin{array}{c}\text { EWI(EDI) }^{\mathrm{c}} \\
(\mu \mathrm{g} / \text { day } / 60 \\
\text { kg b.w. })\end{array}$ & $\begin{array}{l}\text { EDI } \\
\mu \mathrm{g} / \mathrm{kg} \\
\text { b.w. }\end{array}$ & $\begin{array}{c}\text { EWI }(E D I)^{c} \\
(\mu \mathrm{g} / \text { day } / 60 \mathrm{~kg} \\
\text { b.w. })\end{array}$ & $\begin{array}{l}\text { EDI } \\
\mu \mathrm{g} / \mathrm{kg}, \\
\text { b.w. }\end{array}$ \\
\hline $\mathrm{Pb}$ & 25 & $214.3(3.57)$ & $\begin{array}{c}712.98 \\
(101.85)\end{array}$ & 1.7 & $\begin{array}{l}655.86 \\
(93.69)\end{array}$ & 1.56 \\
\hline $\mathrm{Cd}$ & 7 & $60(1.0)$ & $\begin{array}{c}0.34 \\
(0.0457)\end{array}$ & 0.0008 & $\begin{array}{l}69.02 \\
(9.86)\end{array}$ & 0.164 \\
\hline $\mathrm{Fe}$ & 5600 & $48000(800.0)$ & $\begin{array}{c}9038.22 \\
(1291.14)\end{array}$ & 21.52 & $\begin{array}{c}9455.4 \\
(1350.77)\end{array}$ & 22.513 \\
\hline $\mathrm{Zn}$ & 7000 & $60000(1000.0)$ & $\begin{array}{l}5438.64 \\
(776.95)\end{array}$ & 12.95 & $\begin{array}{l}3750.88 \\
(535.84)\end{array}$ & 8.93 \\
\hline
\end{tabular}

${ }^{\mathrm{a} J o i n t ~ F A O / W H O ~ E x p e r t ~ C o m m i t t e e ~ o n ~ F o o d ~ A d d i t i v e s(2004) . ~}$

${ }^{\mathrm{b}}$ Values in parenthesis represent permissible tolerable daily intakes(PTDI) measured by micrograms to every kilogram body weight.

${ }^{c}$ EWI:estimated weekly intakes from consumption of 340 grams of fish every week by adult pearson of $60 \mathrm{~kg}$ body weight according to US EPA(2004). Values in parenthesis represent estimated daily intakes (EDI) by adult person. - $\mu \mathrm{g}$ :microgram $=0.001$ milligram (mg). b.w.: body weight.

\section{DISCUSSION}

Lead (Pb): Short-term exposure to high levels of lead can cause brain damage, paralysis (lead palsy), anaemia and gastrointestinal symptoms, while longer-term exposure can damage the kidneys, reproductive, immune, nervous systems. The most critical effect of low-level of lead exposure is on intellectual development in young children, also, lead crosses the placental barrier and accumulates in the featus. Infants and young children are more vulnerable than adults to the toxic effects of lead where it absorped more readily. Consumption of food containing lead is the major source for the general population (Food Safety Autherity of Ireland, 2009).

The results obtained in Tables 1 and 2 indicated that lead concenteation levels in salted sardine and smoked fishes ranged from 0.633 to 3.823 and 0.488 to 3.57 with means \pm standard error"S.E."values 
of $2.097 \pm 0.224$ and $1.929 \pm 0.211 \mathrm{mg} / \mathrm{kg}$,wet weight, with $100 \%$ incidence of each, respectively.

Nearly similar results in salted fish in Egypt were reported by Nassar et al. (1996); Zaki (1998). Salah El-Dien et al. (2005) examined sixty salted fish (Feseakh) samples collected from different markets in Sharkia governorate, Egypt and recorded that the lead levels ranged from 1.45 to 48.59 with a mean value \pm S.E. of $5.951 \pm 1.1051 \mathrm{ppm}$, wet weight. In addition, all the examined samples exceeded the Codex Alimentarius Commission limit (o.5 ppm) (FAO/WHO, 1992).

These results were higher than that previously reported by Sallam and El-Gazzar (1997). Daoud-Jehan and Abd EL-Aziz (2002) examined 60 ready-to-eat fish products samples, 30 from each of salted sardine and smoked herring of various sizes which were purchased from Alexandria governorate. Lead levels ranged from 0.041 to 0.723 and 0.03 to 0.371 , with mean values of $0.275 \pm 0.044$ and $0.145 \pm 0.017$ ppm, wet weight and the percentage of samples exceeding the permissible limit (o.1 mg/kg according to EOSQC, Egyptian Standard Specification "E.S.S." No.2360, 1993) in salted sardine and smoked herring were $46.67 \%$ and $36.67 \%$, respectively. In Finland, lower lead levels of 4.0 to $177.0 \mathrm{ppb}$ were detected in salted fish (Tahvonen and Kumpulainen, 1996).

The results in Table 3 pointed that lead levels in all the examined samples were exceeding the permissible limit " $0.1 \mathrm{mg} / \mathrm{kg}$ " of EOSQC, No.2360 (1993). Also, these results were above the Codex (2008) guideline of $0.3 \mathrm{mg} / \mathrm{kg}$ for lead element in fish and of $0.2 \mathrm{mg} / \mathrm{kg}$ set by the Commission of the European Communities (2001). These results were consistent with that of Salah El-Dien et al. (2005). Adekunle and Akinyemi (2004) reported elevated lead levels in street vended smoked fish in Nigerian markets, moreover, they stated that the food processing technique accounted for up to seven times increase in fish lead level. Since the United States Environmental Protection Agency (EPA, 1999) has never established a reference dose (RfD), a definitive level cannot be asserted for $\mathrm{Pb}$ in fish. The advisory limit would likely be $1 \mathrm{ppm}$ or greater. Hodson et al. (1984) indicated that the Canadian $\mathrm{Pb}$ limit of 10 ppm was discontinued, but that the British limit remain at 2 ppm in fish, fish paste and canned fish (5 ppm in fried and salted fish). Abou-Arab et al. (1996) indicated that the FAO limit (1983) was 2.0 ppm.

Cadmium $(\mathrm{Cd})$ is a cumulative toxicant that affects kidneys, bone metabolism, the reproductive tract and it is also carcinogenic and an endocrine disruptor. The kidney is the critical organ in humans and other 
mammals exposed for long periods to the relatively small amounts of $\mathrm{Cd}$ that might occur in foods (Satarug and Moore, 2004). Several epidemiological studies in human populations correlated the exposure to Cd with high blood pressure and cardiovascular disease (Telisman et al., 2001).

The results illustrated in Tables 1 and 2 showed only one sample of salted sardine $(6.7 \%)$ contained cadmium concentration of $0.018 \mathrm{mg} / \mathrm{kg}$ and the remaining $93.3 \%$ were below the detectable limit of A.A.S. while in smoked herring samples it ranged from 0.10 to 0.653 with a mean value \pm S.E. of $0.203 \pm 0.044 \mathrm{mg} / \mathrm{kg}$, wet weight, with an incidence of $80 \%$.

High cadmium levels detected in salted sardine and smoked fishes were recorded by Nassar et al. (1996); Sallam and El-Gassar (1997), Zaki (1998) and in salted fish "feseekh" by Salah El-Dien et al. (2005). Daoud-Jehan and Abd El-Aziz (2002) pointed out that Cd concentration in the examined salted sardine and smoked herring samples ranged from 0.04 to 0.129 and from 0.02 to 0.098 with mean values \pm S.E.of $0.081 \pm 0.003$ and $0.07 \pm 0.003 \mathrm{ppm}$ wet weight, respectively. However, lower Cd residues in salted fish were reported by Tahvonen and Kumpulainen (1996) in Finland (9 - $42 \mu \mathrm{g} / \mathrm{kg})$.

The results achieved in Table 3 showed that the $\mathrm{Cd}$ concentrations in all the examined salted sardine samples were below the permissible limit $(0.1 \mathrm{ppm})$ while $73.3 \%$ of smoked herring fishes were above it according to EOSQC, No.2360 (1993).

El-Tahan et al. (1999) found that $\mathrm{Cd}$ and $\mathrm{Pb}$ levels in the examined samples of salted fish (feseekh, melouha and sardine) purchased from Cairo markets were higher than the permissible level. In Egypt, Abou-Arab et al. (1996) reported $\mathrm{Pb}$ and $\mathrm{Cd}$ residues in whole imported sardines were 11.1 and 0.086 and in mackerel were 12.6 and $0.077 \mathrm{ppm}$, respectively.

The studied salted sardine samples were compared with the fresh samples of Moracean true sardine "Sardina pilchardus" analysed by Falco et al. (2006), their mean $\mathrm{Pb}$ was higher $(2.097 \mathrm{vs} 0.04 \mu \mathrm{g} / \mathrm{g})$, while mean concentration of $\mathrm{Cd}$ was about fourty times lower $(0.001 \mathrm{vs}$ $0.04 \mu \mathrm{g} / \mathrm{g})$.

The dietary $\mathrm{Cd}$ absorption rate in humans has been estimated at 5\% (WHO, 1989 and IPCS, 1992) of its total intake. Acute toxicity caused by $\mathrm{Cd}$ contaminated food is very unusal but chronic exposure may be frequent (Satarug et al., 2004). 
Data reported in Table 4 were on a daily basis and for a $60 \mathrm{~kg}$ pearson. The United States Environmental Protection Agency (US EPA, 2004) has recommended weekly consumption of 12 ounces (approx.340g). Children and pregnant mothers are mostly at risk from exposure to toxic metals, so they are advised to strictly follow the recommendation of the US EPA minimum serving of 6 ounces $(170 \mathrm{~g})$ of fish/week (US EPA, 2004). For Pb EDI, values of 1.7 and $1.56 \mu \mathrm{g} \mathrm{Pb} / \mathrm{kg}$ of body weight which were estimated from consumption of salted sardine and smoked herring, respectively, were found below the maximum permissible daily intake proposed by WHO $(3.57 \mu \mathrm{g} \mathrm{of} \mathrm{Pb} / \mathrm{kg}$ b.w.). For $\mathrm{Cd}$, the intakes were found to be 0.0008 and $0.164 \mu \mathrm{g} \mathrm{Pb} / \mathrm{kg}$ of body weight,also far below the WHO provisional daily intake level of $1 \mu \mathrm{g}$ of $\mathrm{Cd} / \mathrm{kg}$ of b.w.

Iron (Fe): It was reported that iron deficiency is the most wide-spread nutritional disorder, and that fish has the potential to contribute to foodbased strategies to reduce the risk of iron deficiency anaemia (Roos et al., 2007). One hundred gram portion of fish may provide almost $20 \%$ of daily $\mathrm{Fe}$ requirement of human. Therefore, both fish may be considered a good supplement source of Fe which performs several vital functions in human body. For example, it serves as a carrier of oxygen from the lungs to the tissues by red blood cells. It also helps to prevent some major health problems (Camara et al., 2005). Also, iron has been shown to be important in the brain as impaired acquisition leads to neurological problems (Connor et al., 2003).

Tables 1 and 2 showed that the iron concentrations in salted sardine and smoked herring ranged from 12.973 to 68.78 and from 14.59 to 65.62 , with mean values \pm S.E. of $26.583 \pm 3.931$ and $27.81 \pm 3.687$ $\mathrm{mg} / \mathrm{kg}$, respectively.

The upper tolerable intake level (UL) of iron in children (0 months- 8 years) and males/females (14-70years) is 40 and $45 \mathrm{mg} /$ day, respectively. The recommended dietary allowance (RDA) of iron for 712 months infants and males/females $51-70$ years is 11 and $8 \mathrm{mg} /$ day, respectively (Institute of Mediciene, 2003). In another study, Fe supplied in the diet must be in the range of $15 \mathrm{mg} /$ day in order to meet daily requirement (Belitz et al., 2004).

Results obtained in Tables 3 and 4 pointed to that $86.6 \%$ of the examined salted sardine and smoked herring samples were compatible with UL of iron. The estimated daily intakes 21.52 and $22.513 \mu \mathrm{g} / \mathrm{kg}$ b.w. were also below the permissible tolerable intake $(800 \mu \mathrm{g} / \mathrm{kg} \mathrm{b.w.)}$ 
stipulated by Joint FAO/WHO Export Committee on Food Additives, 2004.

The metal transporter protein Nramp 2, known also as DMT1 seems to be involved in Cd absorption (Tallkvist et al., 2001). Increased expression of intestinal DMT1 has been found in iron deficiency and hemochromatosis. Increased expression of DMT1, in general, would provide individuals with greater capacity to absorp Fe and possibly $\mathrm{Cd}$. This explains a 3.4-fold increase in Cd body burden in women with low Fe stores (Satarug et al., 2004) and in individuals with low body $\mathrm{Fe}$ stores (Olsson et al., 2002). Therefore, special attention should be given to ensure adequate $\mathrm{Fe}$ intakes to reduce $\mathrm{Cd}$ absorption, because iron deficiency is the most common nutritional disease in the world affecting around 2 billion people (Satarug and Moore, 2004).

Zinc $(\mathrm{Zn})$ is an essential element and micronutrient required for normal growth by both plants and animals and contributes to the development and maintenance of the thymus gland. Zinc plays its role as an integral part of a number of metalloenzymes and as a catalyst for regulating the activity of specific zinc dependant enzymes such as carbonic anhydrase,alkaline phosphatase and alcohol hydrogenase (Moore and Ramamoorthy, 1984) DNA and RNA polymerases (Hayashi et al., 2001).

Tables 1 and 2 revealed that the concentrations of zinc in salted sardine and smoked herring fishes were ranged from 8.713 to 25.063 and from 6.858 to 16.45 with mean values \pm S.E.of $15.996 \pm 1.432$ and $11.032 \pm 0.658 \mathrm{mg} / \mathrm{kg}$ wet weight, respectively. Also, the incidence of detection of zinc in each fish product was $100 \%$. These levels were low in comparison with those in previous studies on salted fish in Egypt (Nassar et al., 1996 and Zaki, 1998). Higher results of zinc level in salted fish (Feseekh) obtained by Salah El-Dien et al. (2005) were ranged from 20.68 to $125.92 \mathrm{ppm}$, with a mean value \pm S.E.of $35.845 \pm$ $2.6007 \mathrm{ppm}$, wet weight.

The results in Table 3 recorded that the zinc levels in examined samples not exceeded the maximum permissible limit $(50 \mathrm{mg} / \mathrm{kg}$, wet weight) proposed by FAO (1983) and MAFF (1995). Also, the estimated weekly and daily intakes were below PTI stipulated by Joint FAO/WHO Export Committee on Food Additives (2004), as shown in Table 4. The too little consumed zinc can cause problems, but also too much is harmful to human health (Agency for Toxic Substances and Disease Registry, 2004). The upper tolerable intake levels of zinc for children 
(1-3 years old) and males/females (19-70 years old) were 0.2 and 1.0 $\mathrm{mg} /$ day, respectively (Institute of Medicine, 2003).

Ako and Salihu (2004) cleared that the smoking as a method of fish preservation may raise the mineral composition of the product to levels that are either beneficial or toxic to humans.

Therefore, analytical data obtained from this study shows that there is health risks from consumption of locally produced smoked herring which were contaminated with high figures of $\mathrm{Pb}$ and $\mathrm{Cd}$ whereas salted sardine were found contaminated with high $\mathrm{Pb}$ level Table 3. Both low-risk group (adolescents and adults) and high-risk group (pregnant mothers and children) should consume fish in moderation since large consumption pattern especially for fishery products may increased health risks.

The finding of this study call for the need to standardize procedures and methods to enhance the quality of this fishery products which must be assessed not only on the basis of physical properties as texture,odour and flavour, but also by the mineral compostion. The method of smoking and duration of exposure to the smoke have been identified as an important factors that affect product quality and acceptability (Indranesa et al., 2000). The crude salt used for salting this products may be contained a fraction of minerals of seawater and must be refined. Globally, further reduction in the levels of environmental contaminants emanating from power plants and other industrial emissions and effluent discharges are highly recommended to reduce contaminant inputs into aquatic environment.

\section{REFERENCES}

Abou-Arab, AAK.; Ayesh, AM.; Amra, HA. and Naguib, K. (1996): Characteristic levels of some pesticides and heavy metals in imported fish. Food Chem 57(4): 487-49.

Adekunle, I.M. and Akinyemi, M.F. (2004): Lead levels of certain consumer products in Nigeria: A case study of smoked fish foods from Abeokuta. Food and Chemical Toxicology., 42: 1463-1468.

Agency for Toxic Substances and Disease Registry (2004): Agency for Toxic Substances and Disease Registry. http://www.atsdr.cdc. gov/toxprofiles/. (accessed January 28, 2009). 
Ako, P.A. and Salihu, S.O. (2004): Studies on Some Major and Trace Metals in Smoked and Oven-Dried Fish. J. Appl. Sci. Environ. Mgt.8 (2)5-9. Full-text Available Online at http://www. bioline.org.br/ja

Al-Ghrais, S.M. (1995): "Heavy metals concentrations in the tissue of sparus sarba forska. "1775 from the United Emirates. Bull. Environ. Contam. Toxicol. 55-581.

Apostoli, P. (2002): Element in environmental and occupational medicine.J. Chromatogr.B.778: 63-97.

Belitz, H.D.; Grosch, W. and Schieberle, P. (2004): Minerals. Food Chemistry. Springer, Berlin; New York: 427-433.

Camara, F.; Amaro, M.A.; Barbera, R. and Clemente, G. (2005): Bioaccessibility of minerals in school meals: comparison between dialysis and solubility methods. Food Chemistry, 92: 481-489.

Canl, M. and Atli, G. (2003): The relationships between heavy metal $(\mathrm{Cd}, \mathrm{Cr}, \mathrm{Cu}, \mathrm{Fe}, \mathrm{Pb}, \mathrm{Zn})$ levels and the size of six Mediterranean fish species. Environmental Pollution., 121: 129-136.

Commission of the European Communities (2001): Commission Regulation (EC) No.221/2002 of 6 February 2002 amending regulation (EC) No. 466/2002 setting maximum levels for certain contaminants in foodstuffs. Official Journal of the European Communities, Brussels, 6 February 2002.

Codex, (2008): Codex Standard for Concentrations and Toxins in Food and Feed (CSCTFF) CODEX STAN 193-195.Joint FAO/WHO Expert Committee on Food Additives/JECFA, 52 pp.

Connor, J.R.; Boyer, P.J.; Menzies, S.K.; Dellinger, B.; Allen, R.P.; Ondo, W.G. and Earley, C.J. (2003): Brain iron acquisition in restless leg syndrome. Neurology, 61: 304-309.

Daoud, Jehan, R. and Abd El-Aziz, A.H.Br. (2002): Determination of some heavy metal residues in salted and smoked fishes. Vet. Med. J., Giza, 50(4): 547-557.

El-Tahan, M.H.; Hassan, S.A.; Awamry, Zeinab, K. and Hamza, Akila, S. (1999): Studies of some heavy metals and nutritive values in salted fish in Egypt. J. Egypt. Ger. Soc.Zool., 29(A): 41-54.

EOSQC (1993): Egyptian Organization for Standardization and Quality Control. Maximum level for heavy metal concentrations in food. Egyptian Specification Standard (E.S.S.) No. 2360/1993 pp.5, Ministry of Industry, Egypt. 
EPA "Environmental Protection Agency" (1999): EPA Region III RiskBased Concentration Table.Revised by J.Hubbard, Superfund Technical Support Section. Philadelphia, Pa., $<$ http:// www.epa.gov/reg3hwmd/risk/riskmenu.htm>

Falco, G.; Llobet, J.; Bocio. A. and Domingo, J. (2006): Daily intake of arsenic, cadmium, mercury and lead by consumption of edible marine species. Journal of Agricultural and Food Chemistry 54: 6106-6112.

$F A O$, (1983): Compilation of legal limits for hazardous substances in fish and fishery products, FAO Fishery Circular. Rome, No. 464, pp. 5-100.

FAO/WHO (1992): Codex Alimentarius Commission. Standard program codex committee on food additives and contaminants $24^{\text {th }}$ Session, Hague, 23-28 March.

Food Safety Autherity of Ireland (2009): Mercury, Lead, Cadmium, Tin and Arsenic in Food. Food Safety Autherity of Ireland. Toxiclogy Factsheet Series, Issue No.1, May 2009.

Food Standard Agency "FSA" of UK (2005): Survy of arsenic in fish and shellfish. Food Survey Information Sheet, 82/05, London, 24p. Available online ww.food.gov.uk/multimedia/pdfs/fsis8205.pf.

Fretheim, K.; Granum, P.E. and Vold, E. (1980): Infuence of generation temperature on the chemical composition, antioxidative and antimicrobial effects of wood smoke. J. Food Sci.,45:999-1002.

Hayashi, K.; Hara, H.; Asvarujanon, P.; Aoyama, Y. and Luangpituksa, $P$. (2001): Ingestion of insoluble dietary fibre increased zinc and iron absorption and restored growth rate and zinc absorption suppressed by dietary phytate in rats. The British Journal of Nutrition 86: 443-451.

Hodson, PV.; Whittle, DM.; Wong, PTS.; Borgmann, U.; Thomas, RL.; Chau, YK.; Nriagu, JO. And Hallett, DJ. (1984): Lead contamination of the Great Lakes and its potential effects on aquatic biota. Advances Envir Sci. Tech. 14: 335-369.

Igado, O.O.; Olopade, J.O.; Onwuka, S.K.; Chukwudi, A.C., Daramola, O.A. and Ajufo, U.E. (2008): Evidence of Environmental Pollution in Caprine Brains obtained from a Relatively Unindustrialized Area in Nigeria. African Journal of Biomedical Research, 11: 305-309.

Ikem, A. and Egiebor, N.O. (2005): Assessment of trace elements in canned fishes (mackerel, tuna, salmon, sardines and herrings) 
marketed in Georgia and Alabama (United States of America). Journal of Food Composition and Analysis., 18: 771-78.

Indranesa, WM.; Hansen, LT. and Gill, TA. (2000): Effect of coldsmoking and drying on the textural properties of farmed Atlantic Salmon (Salmo salar). J.Aquatic Food. Product Tech. 9(1): 47-6.

Institute of Medicine (2003): Dietary Reference intakes: applications in dietary planning. Subcommittee on interpretation and uses of dietary reference intakes and the standing committee on the scientific evaluation of dietary reference intakes (p.248). Washington, DC: Institute of Medicine of the National Academies, The National Academies Press.

IPCS "International Programe on Chemical Safety" (1992): Cadmium . Environmental health criteria 134. Geneva, World Health Organization.

Joint FAO/WHO Expert Committee on Food Additives (2004): Summary of Evaluations Performed by the Joint FAO/WHO Epert Committee on Food Additives (JECFA, 1956-2003), (First through sixty-first meetings). Food and Agriculture Organization of the United Nations and the World Health Organization, ILSI Press International Life Sciences Institute, Washington, DC.

Küçüksezgin, F.A.; Kontas, O.; Altay, E.; Uluturhan, E. and Darilmaz, E. (2006): Assessment of marine pollution in Izmir Bay: Nutrient, heavy metal and total hydrocarbon concentrations. Environment International., 32(1): 41-51

MAFF (1995): Monitoring and Surveillance of Non-radioactive Contaminants in the Aquatic Environment and Activities Regulating the Disposal of Wastes at Sea, 1993. Aquatic Environment Monitoring, Report No. 44. Directorate of Fisheries Research, Lowestoft.

Moore, JW. and Ramamoorthy, S. (1984): Cadmium. In: heavy metals in natural waters. Applied monitoring and impact assessment, Springer Verlag, Berlin, 28-57.

Nassar, A.; Abd Allah, E. and Mohamed, A.A. (1996): Heavy metals contaminants of Egyptian salted fish. $7^{\text {th }}$ Sci. Cong. 17 19 Nov. 1996, Fac.Vet. Med.Assiut. Egypt, 173-182.

Olsson, I.M.; Bensryd, I; Lundh, T.; Ottosson, H.; Skerfving, S. and Oskarsson (2002): Cadmium in blood and urine-impact of sex, 
age, dietary intake, iron status, and former smoking-association with renal effects. Environ. Health Perspect. 110: 1185-1190.

Petric, A. and Waston, P. (2006): Statistics for Veterinary and Animal Science. $2^{\text {nd }}$ Ed. Blackwell Bublishing Ltd, United Kingdom.

Roos, N.; Thorseng, H.; Chamnan, C.; Larsen, T.; Gondolf, U.H.; Bukhave, K. and Thilsted, S.H. (2007): Iron content in common Cambodian fish species: Perspectivas, for dietary iron intake in poor, rurai households. Food Chemistry 104: 1226-1235.

Salah El-Dien, W.M.; Makhouf-Manal, M. and Abd El-Fattah. M.E. (2005): Residual analysis of some heavy metals in salted fish (feseakh) in Sharkia governorate. Zag.Vet. J., 33 (1): 248-254.

Sallam, Kh.I. and El-Gazzar, M.M. (1997): Heavy metal residues in salted and smoked fish marketed at Zagazig City. Alex. J. Vet. Sci., 13(5): 525-532.

Satarug, S. and Moore, MR. (2004): Adverse health effects of chronic exposure to low-level cadmium in foodstuffs and cigarette smoke. Environ. Health Perspect.112: 1099-103.

Satarug, S.; Ujjin, P.; Vanavanitkun, Y.; Baker, JR. and Moore, MR. (2004): Influence of body iron store status and cigarette smoking on cadmium body burden of healthy Thai women and men. Toxicol. Lett. 148: 177-185.

Tahvonen, R. and Kumpulainen, J. (1996): Contents of lead and cadmium in selected fish species consumed in Finland in 19931994. Food Addit.Contam. Aug. Sep. 13(6): 647-654

Tallkvist, J.; Bowlus, CL. and Lonnerdal, B. (2001): DMT1 gene expression and cadmium absorption in human absorptive enterocytes. Toxicol. Lett. 122: 171-177.

Telisman, S.; Jurasovic, J.; Pizent, A. and Cvitkovic, P. (2001): Blood pressure in relation to biomarkers of lead, cadmium, copper, zinc, and selenium in men without occupational exposure to metals. Environ. Res. 87: 57-68.

US EPA "Environmental Protection Agency" (2004): Region I: New England, Floatable Debris, the Problem. Washington, D.C.:U.S. Environmental Protection Agency. http://www. epa.gov/NE/eco/lis/ccmp/floats.html. July21.(originally published published as Long Island Sound Study: Floatable Debrishttp://www.epa.gov/ord/NRMRL/pubs/625r02009/pdf70 .pdf)

WHO "World Health Organization" (1989): Evaluation of Certain Food Additives and Contaminants (Thirty-third Report of the Joint 
FAO/WHO Expert Committee on Food Additives). WHO Technical Report Series No.776. World Health Organization, Geneva.

Zaki, M.S.A. (1998): Heavy metals in fresh and salted marine fish. $4^{\text {th }}$ Vet. Med. Zag. Congress, Hurghada, (2628) August, (1998), PP: 331-340. 